\title{
The immune response does not prevent homologous Porcine epidemic diarrhoea virus reinfection five months after the initial challenge.
}

\author{
Ivan Díaz ${ }^{1}$, Joan Pujols ${ }^{1}$, Esmeralda Cano ${ }^{1}$, Marti Cortey $^{2}$, Núria Navarro ${ }^{1}$, Anna Vidal ${ }^{2}$, \\ Enric Mateu ${ }^{2}$, and Marga Martín ${ }^{2}$ \\ ${ }^{1}$ Institut de Recerca i Tecnologia Agroalimentàries Centre de Recerca en Sanitat Animal \\ ${ }^{2}$ Universitat Autonoma de Barcelona Facultat de Veterinaria
}

January 5, 2021

\begin{abstract}
The aim of the present study was to evaluate the duration of protective immunity against Porcine epidemic diarrheoa virus (PEDV). To that, a two phases study was performed. In the first phase, 75 four-week-old pigs (group A) were orally inoculated (0 days post-inoculation; dpi) with a European PEDV G1b strain and 14 were kept as controls (group B). The second phase started five month later (154 dpi), when animals in group A were homologous challenged and animals in group B were challenged for first time. Clinical signs, viral shedding and immune responses were evaluated after each inoculation, including the determination of antibodies (ELISA and viral neutralisation test, IgA and IgG ELISPOTs using peripheral blood mononuclear cells and lymph node cells) and the frequency of interferon-gamma (IFN- $\gamma$ ) secreting cells. During the first phase, loose stools/liquid faeces were observed in all group A animals. Faecal shedding of PEDV occurred mostly during the first 14 days but, in some animals, persisted until 42 dpi. All inoculated animals seroconverted for specific-PEDV IgG and IgA, and for neutralizing antibodies (NA). At $154 \mathrm{dpi}, 77 \%$ of pigs were still positive for NA. After that, the homologous challenge resulted in a booster for IgG, IgA, NA, as well as specific-PEDV IgG, IgA and IFN- $\gamma$ secreting cells. In spite of that, PEDV was detected in faeces of all pigs from group A, indicating that the immune response did not prevent reinfection although the duration of the viral shedding and the total load of virus shed was significantly lower for previously challenged pigs $(\mathrm{p}<0.05)$. Taken together, the results indicated that, potentially, maintenance of PEDV infection within an endemic farm may occur by transmission to and from previously infected animals and also indicates that sterilising immunity is shorter than the productive life of pigs.
\end{abstract}

\section{Hosted file}

Diaz et al_Duration of PEDV immunity_main text.pdf available at https://authorea.com/users/ 344858/articles/502501-the-immune-response-does-not-prevent-homologous-porcine-epidemicdiarrhoea-virus-reinfection-five-months-after-the-initial-challenge

\section{Hosted file}

Diaz et al_ PEDV immunity_Figure 1_ Clinical scores.pptx available at https://authorea.com/ users/344858/articles/502501-the-immune-response-does-not-prevent-homologous-porcineepidemic-diarrhoea-virus-reinfection-five-months-after-the-initial-challenge

\section{Hosted file}

Diaz et al_ PEDV immunity_Figure 2_RT-qPCR Detection of PEDV in faeces.pptx available at https://authorea.com/users/344858/articles/502501-the-immune-response-does-not-prevent- 
homologous-porcine-epidemic-diarrhoea-virus-reinfection-five-months-after-the-initialchallenge

\section{Hosted file}

Diaz et al_ PEDV immunity_Figure 3_PEDV-specific IgG as determined in a commercial ELISA.pptx available at https: //authorea.com/users/344858/articles/502501-the-immune-response-does-notprevent-homologous-porcine-epidemic-diarrhoea-virus-reinfection-five-months-after-theinitial-challenge

\section{Hosted file}

Diaz et al_ PEDV immunity_Figure 4_PEDV-specific IgA antibodies.pptx available at https: //authorea.com/users/344858/articles/502501-the-immune-response-does-not-preventhomologous-porcine-epidemic-diarrhoea-virus-reinfection-five-months-after-the-initialchallenge

\section{Hosted file}

Diaz et al_PEDV immunity_Figure 5_Viral neutralization test.pptx available at https: //authorea.com/users/344858/articles/502501-the-immune-response-does-not-preventhomologous-porcine-epidemic-diarrhoea-virus-reinfection-five-months-after-the-initialchallenge

\section{Hosted file}

Diaz et al_ PEDV immunity_Figure 6_IgG and IgA ELISPOTs.pptx available at https://authorea. com/users/344858/articles/502501-the-immune-response-does-not-prevent-homologousporcine-epidemic-diarrhoea-virus-reinfection-five-months-after-the-initial-challenge 